\title{
Fostering Accounting's Learning Outcomes through Video Scribe in Vocational High Schools
}

\author{
Dhany Efita Sari, Angga Aji Nugroho, and Yuliati
}

\begin{abstract}
This study aimed to develop a video scribe sparkol learning media on accounting services company at SMK Muhammadiyah 2 Klaten Utara and test their effectiveness on learning outcomes. This is a research and development approach using 4D design (Define, Design, Development, Disseminate). Quasi-experimental research method conduted to test the effectiveness of video scribe on learning outcomes. t-test (independent samples) is used to test the effectiveness of video scribe media on learning outcomes by comparing the learning outcomes of control and experimental groups (normal distribution). The results showed that there was a significant difference between the means student learning outcomes in the control and experimental groups when the posttest conducted (after treatment). With the following test results, $t$ value $>\mathrm{T}$ table, i.e 2.212> 2.024, or seen from Sig ( 2 -tailed, the result of $p$ value is $0.03<0.05$. The results of this study can be a reference material for other researchers related to the use of video scribe in learning that has a positive impact on student learning outcomes.
\end{abstract}

Index Terms-Video scribe, accounting education, learning outcome.

\section{INTRODUCTION}

Education has a goal to produce human resources who are able to compete in the development of the global world. In the world of education, there is a learning process called transfer of knowledge from teacher to student [1]. The process of learning will be ideal when it is implemented correctly. It is said that learning can facilitate the learning process, create innovation in learning, and engage students and facilitate students' understanding of the material [2].

Muhammadiyah Vocational High School 2 North Klaten or we call it SMK Muhammadiyah 2 North Klaten is located in Klaten Regency, Central Java, Indonesia, this school was chosen as a place of research. In the implementation of the learning process, SMK Muhammadiyah 2 Klaten Utara in implementing the learning process still uses conventional methods with the lecture method. The teacher conducts learning by using a service company accounting manual for eleventh grade, the learning process carried out in the conventional way is less varied, resulting in students becoming less focused and often talking to themselves with friends so that the learning process is not conducive.

Based on these problems, learning media can be used as one solution to overcome these problems. Learning media is one of the facilities in the world of education that can help

\footnotetext{
Manuscript received September 14, 2019; revised January 25, 2020.

The authors are with Universitas Muhammadiyah Surakarta, Indonesia (e-mail:
} anggaaji1713@gmail.com). teachers in the learning process [3]. Through learning media suitable with the needs, it can facilitate teachers in implementing learning process to achieve the goals. In the modern era like today, many learning media are developing, one of which is video scribe, which is learning media that uses video-based technology.

In this development research, the product developed is a scribe sparkol video learning media, which is an animated video-based learning medium with a white background, and operates by displaying learning material on video. Video scribe appeared in 2012 created by Sparkol Company in the UK, this software was developed and began to be used in general [4], [5]. Hudaidah (2017) stated that, sparkol video scribe is a web-based application provided by users to create animated presentations. In addition, according to Indriyani, video scribe is a media that makes a unity between images, slides, videos, and added to the sound one of them is sparkol video scribe-based media that is able to make videos in the form of animation, images, writing and sound [6]. Therefore, sparkol video scribe is an animated video-based learning media with accompanying voice, writing, image and dubbing features that can be used in the learning process [7], [8].

This study aims to analyze the conditions before the use of video scribe sparkol learning media and after the use of video scribe sparkol learning media, and analyze the specifications of the media created and test the effectiveness of scribe sparkol video products on student learning outcomes.

\section{METHODS}

\section{A. Participants}

Participants in the research and development are students of class XI Accounting SMK Muhammadiyah 2 Klaten Utara in the 2018/2019 school year consisting of 3 classes with a total of 60 students. So each class there are 20 students who participated in this study.

\section{B. Sampling Techniques}

The sample used in quasi-experimental uses purposive sampling, which is one of the non-random sampling techniques, where the sampling is done not randomly. Purposive sampling technique to determine the research sample with certain considerations aimed at making the data obtained later more representative [9]. The sample used in the study was 60 students from class XII Accounting SMK Muhammadiyah 2 North Klaten in the 2018/2019 academic year which was divided into 3 classes consisting of 20 students in each class.

\section{Research Design}


This study uses quasi-experimental methods, namely experimental activities aimed at finding a symptom or effect that arises, as a result of the existence of certain treatments [10]. Pretest-posttest control group design is used by using one class as a control class, using traditional learning, and one class being an experimental class given intervention in the form of using video scribe sparkol media.

\section{Development Design}

The development model in this research is Reseach and Development using 4D design namely Define, Design, Development and Disseminate. In this study only three stages were carried out and the spreading stage was not carried out due to the short research time and the research which was only carried out within the scope of SMK Muhammadiyah 2 Klaten Utara. According to Sugiyono (2017), research and development methods are research methods used to produce products while testing the effectiveness of certain products. Types of data obtained from interviews in the form of qualitative data and quantitative data from student learning outcomes after passing the post-test. The study was conducted with the model of the experimental class and the control class, namely the experimental class is a class that conducts learning by using video scribe sparkol learning media and the control class is a class that does learning without using video scribe sparkol learning media. From the two classes, tests were conducted to obtain data in the form of student learning outcomes to be compared between the experimental class and the control class.

\section{Define Procedures}

At this stage observations and interviews were conducted to obtain data that at SMK Muhammadiyah 2 Klaten Utara can be used for the development of sparkol learning media. Interviews were conducted to obtain responses and information, and need analysis to obtain the required data, interviews will be conducted with informants, namely accounting teachers of Muhammadiyah 2 Vocational School services in North Klaten. According to Sugiyono, researchers can use several interviews to obtain information [11].

\section{Design Procedures}

Planning is the stage where the sparkol video scribe begins to be designed, at this stage the validity test will also be conducted by media experts and material experts to be able to do field tests. The validity test is to obtain a product feasibility assessment using a 5 points Likert scale, namely: strongly agree, agree, neutral, disagree and strongly disagree [12]. Products that have passed the validity test from the material expert and the media expert will undergo a product revision before conducting the field test.

\section{Development Procedures}

At the development stage, a field test was conducted using sparkol video scribe products. The field test was conducted at SMK Muhammadiyah 2 Klaten Utara with the experimental class and the control class, by comparing the average student learning outcomes between those using video scribe learning media with conventional learning or traditional learning. Then the control and experimental class students were given a post-test, this was done to get quantitative data as a result of student learning. Posttest is an activity to give questions to students after going through learning.

\section{Disseminate Procedures}

The distribution phase is the stage where the product in the form of a sparkol video scribe is ready to be spread. The product has gone through various stages to produce a learning media that can improve student learning outcomes, the product will be disseminated to be used in the learning process as a scribe-based learning media.

\section{RESUlTS AND DisCUSSIONS}

\section{A. Results}

The result of the research development is a product in the form of a learning media video scribe sparkol that can improve student learning outcomes. Sparkol scribe video learning media is scribe video-based learning media featuring animation, accompaniment and dubbing. According to Susanti (2019), video scribe appeared in 2012 created by Sparkol, a company in the UK, this software was developed and began to be used in general. Then Indriyani, sparkol video scribe is a media that makes a unity between images, slides, videos, and plus the sound one of them is sparkol video scribe-based media that is able to make videos in the form of animation, images, text and sound [6]. The use of this software in addition to an easy manufacturing process also produces an attractive appearance and is based on handwriting animation (Basuki 2018).

The sparkol scribe video in this study has been assessed by material experts and media experts to produce products that are feasible and can be used in the learning process. The results of the assessment by material experts get an average of 3.9 with "good" criteria and the material used does not get revised. The results of the assessment of media experts get an average score of 3.5 with the criteria of "good" but there are still improvements to the product in the form of sound effects that are too loud and letters that are too small and thin. Products that have experienced improvements from media experts have been improved before being used in field trials.

At the field test stage, the test validity and reliability of the questions were carried out by the class without treatment and showed, of the 15 questions used in the study there were 13 valid questions. The reliability test was conducted to test the consistency of valid items, table 3 shows the reliability result is 0.867 with high criteria.

TABLE I: RELIABILITY TEST RESULTS Reliability Statistics

\begin{tabular}{cc}
\hline \hline \multicolumn{2}{c}{ Reliability Statistics } \\
\hline Croncbach's Alpha & $\mathrm{N}$ of items \\
0,867 & 13 \\
\hline \hline
\end{tabular}

Normality test used Kolmogorov-Smirnov [13]. Data will be said to be normal if L count> L table or significance level> 0.05 .

TABLE II: NORMALITY TEST RESULTS

\begin{tabular}{lllll}
\hline \hline \multirow{2}{*}{ Learning outcome } & \multicolumn{3}{c}{ Kolmogrov-Smirnov } \\
\cline { 3 - 5 } & & Statistic & Df & Sig \\
\hline Value & Control class & .135 & 20 & .200 \\
& $\begin{array}{l}\text { Experiment } \\
\text { class }\end{array}$ & .140 & 20 & .200 \\
\hline \hline
\end{tabular}


Based on the table it can be seen that the results of the normality test using the Kolomogrov-Smirnorv technique are normally distributed, this can be proven through the normality of the control class $0.200>0.05$ and the normality test of the experimental class $0.200>0.05$. Homogeneity test is done before the experiment with the aim to find out whether the learning outcomes come from the same population or not. Homogeneity test uses the Levene Statistics formula in Widianto (2014) with the application of SPSS for Windows version 23. The results are said to be homogeneous if the significance level is $>0.05$.

TABLE III: HOMOGENITY TEST RESULTS

\begin{tabular}{clll}
\multicolumn{4}{c}{ TABLE III: HOMOGENITY TEST RESULTS } \\
\hline \hline Levene Statistics & df 1 & df 2 & Sig \\
\hline .219 & 1 & 38 & .643 \\
\hline \hline
\end{tabular}

Based on these tables it can be concluded that the homogeneity test results are $0.643>0.05$, so the population in this study can be concluded homogeneous. After obtaining data that the homogeneous population and the data are normally distributed, an independent sample t-test was conducted to test the hypothesis in this study. The following table 4 shows the results of the independent sample t-test, with the test results known $\mathrm{T}$ value $>\mathrm{T}$ table, then the conclusion of this test means that null hypotheses are rejected.

TABLE IV: INDEPENDENT SAMPLE T-TEST RESULT

\begin{tabular}{lccc}
\hline \hline T value & T table & Sig. & Summary \\
\hline 2.212 & 2.024 & .033 & Null hyphoteses rejected. \\
\hline \hline
\end{tabular}

The conclusion of the t-test can be formulated that there is a significant difference between the mean score of the learning outcomes of the experimental class and the control class. From the results of the post-test, we get $t$ value $>\mathrm{T}$ table, i.e 2,212>2,024, or seen from Sig (2-tailed, the result of $\mathrm{p}$ value is $0.03<0.05$.

\section{B. Discussions}

The learning process is a transfer of knowledge from teacher to student. One result of the learning process is in the form of grades or student learning outcomes. Learning outcomes are indicators of quality and knowledge possessed by students [14]. According to Pane \& Darwis Dasopang, in learning and teaching activities, students are the subjects and objects of educational activities (2017). Meanwhile, the learning conditions at SMK Muhammadiyah 2 Klaten Utara still use conventional methods by way of lectures, it makes students become bored and difficult to concentrate and the learning takes place. According to Hamalik, the use of instructional media in the teaching and learning process can arouse new desires and interests, arouse motivation, stimulate learning activities, and bring biological influences on students [15].

Based on these conditions, this study developed a video-based learning media scribe with teaching materials from accounting services companies KD 3.1 for class XI which includes material about the introduction of service companies, service company characteristics, weaknesses and strengths of service companies. The purpose of developing sparkol video scribe media is to provide solutions in overcoming problems of students who have difficulty concentrating in learning and improving student learning outcomes.

Scribe video media are developed in various stages, products in the form of video scribes are assessed by media experts and material experts through expert validation sheets to get viable products. Learning media must be developed and assessed effectively with input from all stakeholders before broad implementation. So, it is important to use learning media so that learning runs well [16]. According to Sherin, video is a popular tool for teacher education and development professionals [17], then Rieger and Slocum, sharing conceptual memos accompanied by video recordings and transcripts that can provide feedback to groups of students. In this case various conceptual memos accompanied by the video can provide stimulation to groups of students to provide feedback on the material presented [18].

The choice of scribe video based learning media was chosen because scribe video based learning media was in accordance with technological and information developments. According to Winthereik and Johannsen, the development of informatics techniques has also been felt by families, which makes video-based informatics techniques as an educational medium [19]. In Jacobs, and Seago's research on Wilfrie, the teacher uses video to promote knowledge content and knowledge as a way to develop pedagogical competencies. In addition, according to [20], Popular videos will be analyzed very often, Olcay (2012), reflecting video footage, teachers will develop a better understanding of the relationship between their language use and the learning opportunities they provide to their students. Thus, video scribe can be used as a learning medium as one solution to the problems of students who have difficulty concentrating in learning [21].

Scribe sparkol video learning media is an animated video that provides several features such as animation, effects and dubbing. According to [22], animation projects can teach students about animation and software and create content. Through the creation of animated content, video scribe can be used as a learning medium in the learning process. According to [23] Animation is also evidence of the development of science with a visual system [24], [25]. Therefore, in the video scribe sparkol learning media there are facilities that support the delivery of material in the form of animation. Scribe sparkol video learning media has various features, namely dubbing (voice acting), soung effect (accompaniment sound), animation (moving images). These features can be selected and combined to produce a video scribe product that can be used in the learning process. Media in the form of videos with sound and images can be used by teachers as mentors [26].

Based on some of these theories, this study develops sparkol video scribe learning media. After the product is declared suitable for use through the assessment of material experts and media experts, the research continues with field trials. The study was conducted in class XI AK 1 as a control class that is a class that does learning without using video scribe totaling 20 students, class XI AK 2 as an experimental class that is a class that carries out the learning process using video scribe sparkol learning media totaling 20 people and 
classes XI AK 3 is a class without actions for question validation with a total of 20 students.

At the field trial stage, a post-test was conducted to obtain data in the form of learning outcomes which were used as a comparison between learning conducted using sparking video scribe learning media and classes that conducted learning without using sparking scribe video learning media. The average learning outcomes of the experimental class was 63.25 while the average learning outcomes of the control class was 51.5 .

Dellyardianzah with her study entitled Using Video-Based Scribe Learning Media to Improve Student Learning Outcomes in Economic Subjects in class X SMAN 10 Pontianak, showed that from the results of the study, the average results of the experimental class 75.83 and control class 69.15. Students who complete the experimental class of 26 students. So that the use of media-based learning video clerks can increase income in economic subjects class $\mathrm{X}$ SMAN 10 Pontianak [27].

In line with Hudaidah, Kholidin and Safitri with their studies using sparkol scribe video learning media showed an average pretest result of 44.3 with a very low category and then an average posttest of 89.6 with a good category [28]. An increase of $45.3 \%$. Then Munandar in his study also used scribe sparkol video learning media on moral subjects in MTSN 02 Raman Utara. The results of the study of the expert material assessment got a $88 \%$ feasibility score of $91 \%$ of media experts accompanied by very interesting teacher responses and the results of the small group test were $89 \%$ and the results of the field trials were $97 \%$. This shows that the sparking video scribe learning media is accepted and becomes an interesting learning media in accordance with the changing times (2018).

Based on data analysis with reference to some relevant previous research, it can be concluded that the scribe video-based learning media can have an impact on the learning process and student learning outcomes. This can be known through the posttest results of the control class and the experimental class that is 51.50 compared to 63.25 with a difference of 11.75 .

\section{CONCLUSION}

The product developed in this study is a scribe video-based learning media using sparkol video scribe applications. Scribe videos are arranged with a white screen display with animations to convey learning material, there are accompanying sounds and images to provide innovation in the learning process and help students to understand the material.

There is a significant difference in the mean score of learning outcomes between the control group and the experimental group based on the results of the post-test given. The average student learning outcomes before using scribe video learning media is 51.50 while the average learning outcomes after using video scribe is 63.25 . The results of this study can be a reference material for other researchers related to the use of video scribes in learning that have a positive impact on student learning outcomes.

\section{CONFLICT OF INTEREST}

The authors declare no conflict of interest.

\section{AUTHOR CONTRIBUTIONS}

All Author carried out all the research processes, including analyzing the data and wrote the paper

\section{ACKNOWLEDGMENT}

Author thanks to Universitas Muhammadiyah Surakarta, Indonesia for supporting us to join this conference and publication.

\section{REFERENCES}

[1] C. Macaulay and V. E. Cree, "Transfer of learning: Concept and process," Soc. Work Educ., vol. 5479, no. 1999, pp. 183-194, 2007.

[2] H. Coates, "A model of online and general campus-based student engagement," Assess. Eval. High. Educ., vol. 32, no. 2, pp. 121-141, 2007.

[3] M. J. Eady and L. Lockyer, "Tools for learning: Technology and teaching strategies," Learning to Teach in the Primary School, Australia: Queensland University of Technology, 2013, p. 71.

[4] B. Susanti, "Penggunaan media pembelajaran video scribe untuk meningkatkan motivasi belajar siswa kelas $\mathrm{v}$ madrasah ibtidaiyah at-taqwa pinang," Nat. J. Kaji. Penelit. Pendidik. dan Pembelajaran, 2019.

[5] Gabriel, “About sparkol," Say Hello to VideoScribe's New Support System, 2014 .

[6] I. Indriyani and F. G. Putra, "Media pembelajaran berbantuan sparkol materi program linier metode simpleks," Desimal J. Mat., 2018.

[7] S. Sidek and M. Hashim, "A field survey on the types of videos and learning approaches deemed appropriate for the 21 st century teaching and learning," Int. J. Sci. Res. Publ., vol. 7, no. 6, pp. 303-307, 2017.

[8] A. Sofiya and B. Yulianto, "The development of sparkol videoscribe based internet learning media in improving writing skills of indonesian language for elementary school students," in Proc. 2nd International Conference on Education Innovation (ICEI 2018), 2018, vol. 212, pp. $108-111$.

[9] D. Ary, L. C. Jacobs, C. Sorensen, and A. Razavieh, Introducation to Research in Education, 8th ed. California: Cengage Learning, 2010.

[10] J. W. Creswell, Research Design: Qualitative, Quantitative, and Mixed Methods Approaches, Los Angeles: Sage Publications, 2014.

[11] Sugiyono, "Pendekatan kuantitatif, kualitatif, kombinasi, R\&D dan penelitian evaluasi," Metodelogi Penelitian, 2017.

[12] D. M. Gall, P. J. Gall, and R. W. Borg, Educational Research: An Introduction, USA: Pearson Education, Inc, 2003.

[13] J. W. Creswell, Educational Research: Planning, Conducting, and Evaluating Quantitative and Qualitative Research, Boston: Edward Brothers, Inc., 2012.

[14] D. Firdaus, "Pengaruh kecerdasan emosional (EQ) dan motivasi belajar terhadap hasil belajar biologi siswa SMA 3 negeri kota palopo | daud | jurnal pendidikan dan pembelajaran (JPP)," Urnal Pendidik. dan Pembelajaran Univ. Negeri Malang, vol. 9, no. 2, pp. 243-255, 2012.

[15] O. Hamalik, Proses Belajar Mengajar, Jakarta: Bumi Aksara, 2001.

[16] R. Hernan et al., "Impact of patient education videos on genetic counseling outcomes after exome sequencing," Patient Educ. Couns., vol. 49, no. 6, pp. 353-361, Aug. 2019.

[17] M. G. Sherin and E. B. Dyer, "Teacher self-captured video: Learning to see," Phi Delta Kappan. 2017.

[18] Rieger and Slocum, "Manajemen sumber daya manusia," Edisi Pert., Jakarta: Salemba Empat, 2011.

[19] B. R. Winthereik and J. Nis, "Making technology public: Challenging the notion of script through an e-health demonstration video," J. Inf. Technol. People, vol. 12, no. 2, pp. 105-112, 2008.

[20] M. Vranješ, V. Bajčinovci, R. Grbić, and D. Vajak, "No-reference artifacts measurements based video quality metric," Signal Process. Image Commun., vol. 78, pp. 345-358, Oct. 2019.

[21] J. Fredricks, W. Mccolskey, J. Meli, J. Mordica, B. Montrosse, and K. Mooney, "Student engagement in upper elementary through high school: A description of Measuring student engagement in upper elementary through high school: a description of 21 instruments," Institute of Education Sciences (IES), Washington DC, 2011. 
[22] S. Connolly, "The new addington primary schools animation project: Using animation to build community relationships between schools," $J$. Assist. Technol., vol. 5, no. 1, pp. 37-39, Mar. 2011.

[23] M. Oesker, H. Hecht, and B. Jung, "Psychological evidence for unconscious processing of detail in real-time animation of multiple characters," J. Vis. Comput. Animat., vol. 11, no. 2, pp. 105-112, May 2000.

[24] K. Soika, P. Reiska, and R. Mikser, "The importance of animation as a visual method in learning chemistry," Fourth Int. Conference on Concept Mapping, 2010.

[25] G. Shabiralyani, K. S. Hasan, N. Hamad, and N. Iqbal, "Impact of visual aids in enhancing the learning process case research : District Dera ghazi khan," J. Educ. Pract., vol. 6, no. 19, pp. 226-234, 2015.

[26] M. Mosley Wetzel, J. V. Hoffman, and B. Maloch, "A video-based mentoring tool for cooperating teachers coaching preservice teachers: Supporting reflection around literacy practice," Lit. Res. Pract. Eval. vol. 5, pp. 81-103, 2015.

[27] Undefined Dellyardianzah, "Penggunaan media pembelajaran berbasis video scribe untuk meningkatkan hasil belajar siswa pada mata pelajaran ekonomi," vol. 6, no. 10, pp. 1-7, 2017.

[28] K. Kholidin, H. Hudaidah, and S. Safitri, "Pengembangan media pembelajaran menggunakan program video scribe sparkol pada mata pelajaran sejarah kelas xi di sekolah menengah Atas," Criksetra J. Pendidik. Sej., vol. 6, no. 2, 2017.

Copyright $\odot 2020$ by the authors. This is an open access article distributed under the Creative Commons Attribution License which permits unrestricted use, distribution, and reproduction in any medium, provided the original work is properly cited (CC BY 4.0).

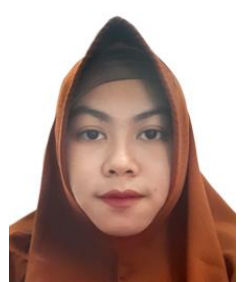

Dhany Efita Sari was born in Karanganyar, Indonesia, on December 12, 1991. She got the degreed from Universitas Sebelas Maret, Indonesia, major field in accounting education on 2013. In 2016 she got her postgraduate program in Universitas Sebelas Maret also and major field in economics education, concentrated in accounting on. This year, in 2019, she is a $\mathrm{PhD}$ candidate on major field accounting education in Universiti Pendidikan Sultan Idris, Malaysia. She is a lecturer in accounting education program, Universitas Muhammadiyah Surakarta, Indonesia. Her research interest and previous studies is on financial literacy among students and children, and in educational technology also.

Latest publication of Mrs. Sari is on Quizlet, Kahoot, Quipper school and anothers software or application in educational technology. In financial literacy, her publication is on financial literacy education for children, students, and family.

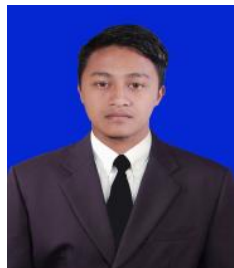

Angga Aji Nugroho was born in Wonogiri, Indonesia, on April 17, 1997. He is students from Universitas Muhammadiyah Surakarta, Indonesia, $\mathrm{He}$ is candidat Undergraduate degree, major field in Accounting Education..

Last activity in campus, Mr. Angga is activist on student organization accounting education association, Universitas Muhammadiyah Surakarta, Indonesia as a leader in the field of art and culture.

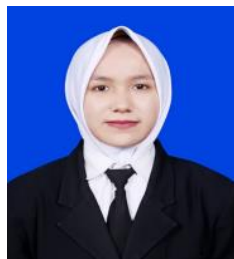

Yuliati was born in Wonogiri, Indonesia, on July 19th 1994. She graduated from Universitas Muhammadiyah Surakarta, Indonesia, it's undergraduated degree, major field accounting education on 2019.

She is a activist in IMM Organization and students representative organization Universitas Muhammadiyah Surakarta in 2016 until 2018. She makes an Intermediate Accounting Book collaboration with lecturer of Accounting Education Universitas Muhammadiyah Surakarta in 2019. Her research interest is Marketing of Educational Server In 4.0.

Latest activity after graduated, she joined in the acceleration of Scopus publication team and also become a member of co-author Scopus in accounting education program, Universitas Muhammadiyah Surakarta, Indonesia. 